\title{
Foliar ANATOMy OF THE SPECIES Lantana camara AND L. radula (VERBENACEAE) ${ }^{1}$
}

\author{
Anatomia Foliar das Espécies Lantana camara e L. radula (Verbenaceae) \\ PASSOS, J.L. ${ }^{2,3}$, MEIRA, R.M.S.A. ${ }^{3}$ and BARBOSA, L.C.A. ${ }^{2}$
}

\begin{abstract}
The species Lantana camara, commonly used as ornamental, has spread worldwide becoming one of the world's most important weeds. To develop new methods of control of this plant, it is essential to distinguish it from other species of the same genus, and this is usually accomplished through taxonomic studies of fertile samples. Considering the similarity between $L$. camara and $L$. radula, and the consequent difficulty in distinguishing one from the other when only sterile samples are available, this work aimed to investigate the use of the anatomical characteristics of the leaves of both species as tools for supporting correct classification. The leaves of $L$. camara and $L$. radula were anatomically examined by light microscopy and scanning electron microscopy. The major differences were observed in the petiole, which presented secretory idioblasts in L. camara. Secretory idioblasts were observed in the leaf blades of $L$. camara and Crystalliferou idioblasts were found in L. radula. Glandular and nonglandular trichomes as well as the abaxial surface are different in each species. Such results can support the strategies aiming at the control of $L$. camara without interfering with $L$. radula.
\end{abstract}

Keywords: idioblasts, L. camara, L. radula, glandular trichomes, weed plant.

RESUMO - A espécie L. camara tem sido usada há séculos como ornamental e, consequentemente, espalhou-se pelo mundo, tornando-se uma das mais importantes plantas daninhas. Na busca de novos métodos de controle para essa planta, é essencial distinguir espécies do mesmo gênero, o que usualmente é feito com estudos taxonômicos de amostras férteis. Considerando a similaridade entre $\boldsymbol{L}$. camara e $\boldsymbol{L}$. radula, e a consequente dificuldade em distingui-las quando somente amostras estéreis estão disponiveis, entendeu-se como necessário investigar o uso de características anatômicas das folhas como fonte de informação adicional para a distinção dessas duas espécies. As folhas de L. camara e $\boldsymbol{L}$. radula foram examinadas sob microscopia de luz e microscopia eletrônica de varredura. A diferença mais marcante observada foi a presença de idioblastos nos peciolos de L. camara e $\boldsymbol{L}$. radula. Na lâmina foliar de $\boldsymbol{L}$. camara foram observados idioblastos secretores e em $\boldsymbol{L}$. radula foram encontrados idioblastos cristaliferos. Os tricomas glandulares e não glandulares, bem como a superficie abaxial, apresentam diferenças morfológicas evidentes em cada espécie.

Palavras-chave: idioblastos, L. camara, L. radula, tricomas glandulares, planta daninha.

\section{INTRODUCTION}

The genus Lantana is native from tropical and subtropical America, with some species occurring in Asia and tropical Africa. The species Lantana camara has spread across the world, causing problems in several countries where it was introduced as ornamental. In these countries it has adapted very well to the local climatic conditions, invading forests,

1 Recebido para publicação em 10.6.2008 e na forma revisada em 13.11.2009.

2 Department of Chemistry, Universidade Federal de Viçosa - UFV, 36571-000 Viçosa-MG, Brazil, Phone (31) 3899-3205, $<$ julpassos@hotmail.com>; ${ }^{3}$ Department of Botany - UFV. 
pastures, and other areas where entropic interventions have occurred. Besides being toxic for many domestic animals (Barreto et al., 1995), L. camara has an allelopathic effect on the surrounding vegetation (Sharma et al., 1988) interfering in natural communities, and reducing the local diversity. So, countless attempts have been made aiming to control this weed, but with limited success (Sharma et al., 1988; Day et al., 2003).

There are several morphological varieties in the plants from the genus Lantana (Silva, 1999) and this hinders their identification in the field. Countless taxonomic problems have been reported and these plants are frequently classified incorrectly (Silva, 1999; Salimena, 2002). The separation between some species of Lantana is normally made by the analysis of fertile samples, which is difficult when the plants are sterile.

In Minas Gerais, Lantana radula $S W$ appears together with L. camara. These two species are morphologically similar in many aspects, in the absence of fertile branches. Differently from $L$. camara, L. radula has a more limited occurrence, being found from Central America to Brazil, with the southern limit being in the state of Minas Gerais.

The continuous attempt to control L. camara can affect other species such as L. radula, due to incorrect taxonomic identification. For a long time, anatomic studies have shown to be an important tool associated with taxonomic studies, mainly when there is no reproductive organ in the investigated sample (Solereder, 1908; Metcalfe \& Chalk, 1950). In some cases, leaf anatomy allows the identification of hierarchically inferior levels (Alves et al., 2002; Sartori \& Tozzi, 2002). The objective of the present study was to characterize the anatomy of the leaves of L. camara and $L$. radula, aiming to find characteristics that could contribute for the identification of sterile samples of these species.

\section{MATERIAL AND METHODS}

The botanical material was obtained from plants cultivated in pots and maintained in a greenhouse on the campus of the
Universidade Federal de Viçosa $\left(20^{\circ} 45^{\prime 2} 24^{\prime \prime S}\right.$ and $42^{\circ} 52^{\prime} 22^{\prime \prime} \mathrm{WO}, 680 \mathrm{~m}$ of altitude).

The plants were identified by a specialist and herborized, with a voucher specimen of each plant being deposited at the VIC Herbarium (under the numbers 30159 L. camara and 30160 - L. radula) in the Department of Plant Biology of the Universidade Federal de Viçosa (UFV).

Mature leaves from the $3^{\text {rd }}$ to the $5^{\text {th }}$ nodes were collected from three plants of each species. Fresh petiole and leaf blade samples were cut transversally using a table microtome (model LPC, Rolemberg and Bhering Commercial and Importation LTDA, Belo Horizonte, Brazil), with the cuts being stained for 5 minutes with Safrablau (Kraus \& Arduim, 1997) and the blades mounted with glycerolized water.

Three leaf fragments were affixed for 48 hours in FAA $_{70}$ (formaldehyde, acetic acid, ethanol 50\%, 5:5:90, v/v) (Johansen, 1940) and preserved in $70 \%$ ethanol. Samples with approximately $5 \mathrm{~mm}^{2}$ of leaf blade and petiole were dehydrated in an ethylic series $(70 \%$ to 95\%) and embedded in a histological resin (Historesin Leica). To make the penetration of the solutions easier, the samples were maintained in a dehydrator under constant vacuum. The samples were sectioned in transversal and longitudinal planes, with an automatic advancement rotary microtome (RM 2155, Leica), using a glass razor. Cuts 5 to $7 \mu \mathrm{m}$ thick were distended on glass plates, stained with Blue Toluidine in $\mathrm{pH} 4.4$ (O'brien \& Maccully, 1981) during 10 minutes and mounted with a synthetic resin (PermountFisher).

For diaphanization, three leaves from the $3^{\text {rd }}$ to the $5^{\text {th }}$ node were individually selected from each species, with leaves being collected from three specimens. The leaves were subdivided into apical, median and base regions, and for each region two samples per leaf were used to analyze the abaxial and adaxial surfaces. These samples were treated with aqueous sodium hydroxide at $10 \%$, washed with running water and stained with aqueous safranin at 1\% (Johansen, 1940). Tthe plates were mounted with jelly glycerinate. The number of glandular and nonglandular 
trichomes was quantified for the abaxial and adaxial surfaces in each region under a light microscope (magnification of 40 and total area of $29.7 \mathrm{~mm}^{2}$ ). In this experiment, 45 areas of approximately $0.22 \mathrm{~mm}^{2}$ each were examined for each surface and region (apical, median and base). The number of trichomes was calculated independently for each surface and evaluated portions. The results were analyzed by the Tukey's average test.

Observations and photographic documentation were made with a light microscope (model AX70TRF, Olympus Optical) equipped with U-Photo system.

For the description of the micromorphology of the glandular and non-glandular trichomes, the samples were dehydrated in an ethanol series, submitted to critical point drying with liquid $\mathrm{CO}_{2}$ and covered with metal gold to $20 \mathrm{~nm}$ of thickness (SCA 010, Balzers, Liechtenstein). Such samples were analyzed and the images obtained in a scanning electron microscope (SEM) Zeiss model LEO 1430VP (Cambridge, England).

\section{RESULTS}

L. camara and L. radula presented some common morphological leaf characteristics, such as simple leaf, complete with petiole and pubescent; opposite-decussate phylotax, sharp acuminated top and serrated edge.

The petioles of the two species (Figures 1AD) are flat and convex on the adaxial and abaxial surfaces, respectively. They are covered with a thin cuticle and the epidermis is uniseriate with regular size cells and several types of glandular and non-glandular trichomes throughout its extension. In the subepidermic portion there are nearly three layers of collenchyma. The vascular system is collateral for both evaluated species. In L. camara, the vascular system is open, forming a flattened arch in the "V" form with two accessory bundles located dorsally (Figure 1A). In $L$. radula, the vascular system is open with curved edges, in a horseshoe form, by two accessory bundles arranged laterally (Figure 1C). Groups of idioblasts located laterally in the cortical parenchyma were observed in L. camara (Figure 1B) but not visualized in L. radula (Figure 1D).
In both species, the venation pattern is of pinnate type, with simple lateral craspedodromus venation, where all side veins and their branches end in the edge (not documented). The areoles had a quadrangular format with single venation (Figures $1 \mathrm{E}, \mathrm{F}$ ).

On the surfaces of the leaf blade of L. camara (Figures 2A, D) and L. radula (Figures 2E, I), the epidermic cells presented a winding outline with recesses in the form of "U". In $L$. radula, the abaxial surface is not flat, presenting depressed regions, where glandular trichome incidences are common (Figure 2H).

The stomata occur in both surfaces (amphistomatic), though they were rare in the adaxial surface. They were located at the same level as the other epidermic cells, in the form of complex diacytic and anomocytic stomata (Figures 2A, C, E, H).

Glandular and non-glandular trichomes were found scattered through the entire petiole and leaf blades, with types varying according to the species (Figures 3, 4 and 5).

Nonglandular trichomes found in both Lantana species (Figures 3A, F) are of the conical type, presenting a large base and a thin extremity, and ornamentations on the wall. These trichomes are uni or bi-celullar and presented a set of bulky epidermis cells arranged radially at the base (Figures 3C, F). In L. camara (Figures 3A, C, E) the trichomes were visually larger (Figures 3B, D, F) and more numerous (Table 1), compared to those found in $L$. radula. As the frenquency of nonglandular trichomes in $L$. radula was very low for the two leaf surfaces (inferior to 1, Table 1) no statistical difference was observed. For L. camara, trichome frequency in the adaxial surface was double the value of the abaxial surface (Table 1). Regarding the evaluated regions, no differences were observed in terms of trichome frequencies for the two species investigated (Table 2).

Three types of capitate glandular trichomes were identified (Figures 4 and 5). Type I: multicellular, with a cell at the base, two lengthened cells of variable length on the stalk, a short cell on the neck and the head multiseriate with two to eight cells. Type II: multi-cellular with a base cell, a short cell on the neck and with one, two or four apical cells 
in the secretory head. Type III: bi-cellular, with a base short cell and an apical dilated cell composing the secretory head, with its cuticle expanded during the secretory phase. In L. camara, trichomes of types I (Figures 4A, H), II (Figures 4I, J) and III (Figures 4L, M) were visualized. In $L$. radula, trichomes of types I (Figures 5A, B), II (Figures 5C, D, E, F) and III (Figures 5G, I) were also observed. However, the difference between the two species consists in the number of cells in the head of the capitate trichomes of types I and II. Trichome frequency was found to be higher in the abaxial surface for both species (Table 1). Regarding the evaluated regions (base, median and top) no statistical differences were observed for the middle frequency of the trichomes, the exception being $L$. radula in the abaxial surface (Table 2).
For the two species, the leaf blades presented uniseriate epidermis cells with thin periclinal walls and a relatively thick cuticle. The mesophyll is dorsiventral, with two layers of palisade parenchyma (Figures 6A, B) and three to four layers of spongy parenchyma, which is more compact in L. camara (Figure 6A) that in $L$. radula (Figure 6B). In L. camara, secretory idioblasts found in the mesophyll were similar to those in the petiole. (Figure 6C). The idioblast cytoplasm was stained purple with Blue Toluidine (Figures 6A, C, E). In L. radula, only idioblasts containing styloid crystals in the chlorophyllian parenchyma were visualized (Figure 6D). The vascular system of the central ein (Figures 6E, $\mathrm{F}, \mathrm{G}, \mathrm{H})$ is of collateral type, in the form of an open arch in both species. However, in L. radula, it is more curved, having the remotest extremities of the arch.

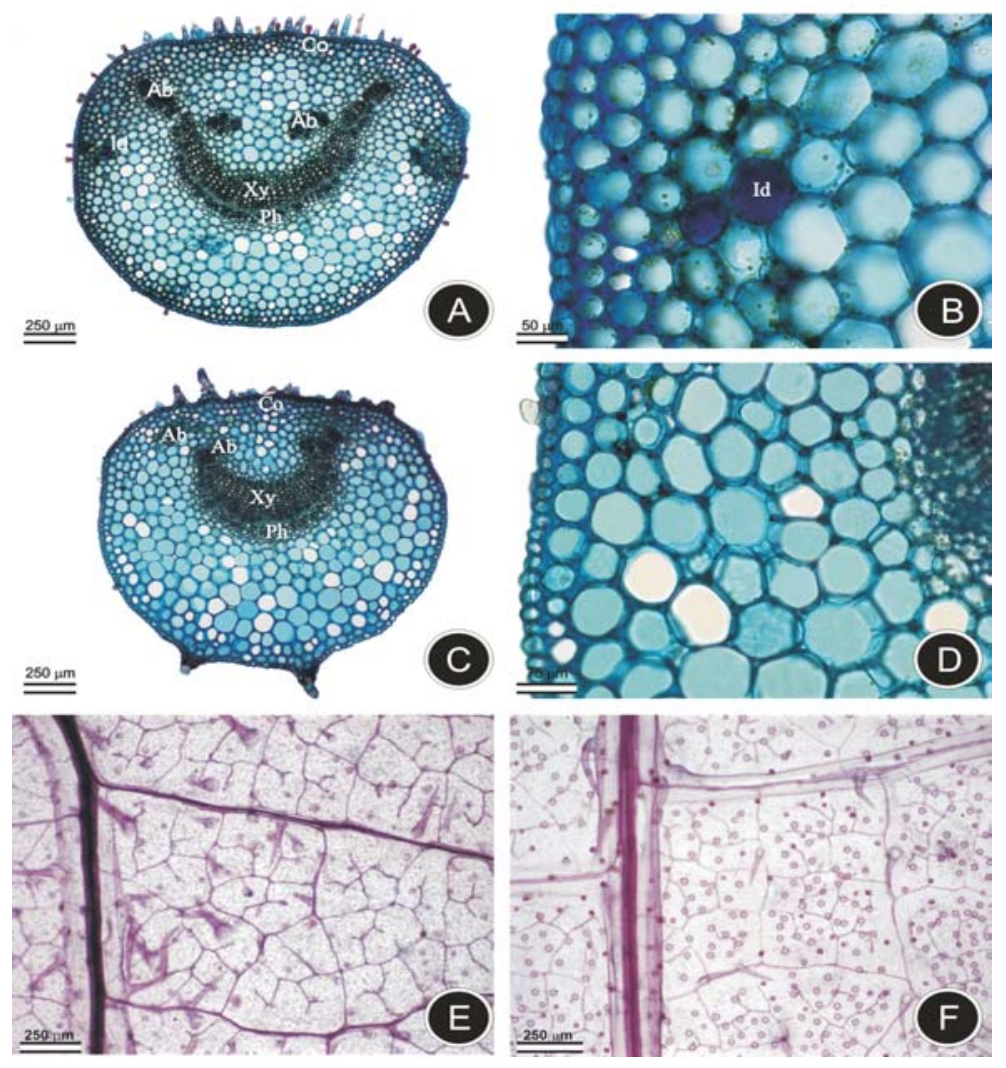

Figure 1 - Leaves of Lantana camara (A, B and E) and Lantana radula (C, D and F). A to D-Cross section of the distal region of the stained petioles.E and F-Leaf clearing of the leaf blades showing venation. A and C-General view. B -Detail of the cortex showing the secretory idioblasts. $\mathrm{D}-$ Cortex. $\mathrm{E}$ and F-Areoles. $\mathrm{Id}=$ idioblasts, $\mathrm{Co}=$ collenchyma $, \mathrm{Xy}=\mathrm{xylem}, \mathrm{Ph}=\mathrm{phloem}, \mathrm{Ab}=$ accessory bundles. 


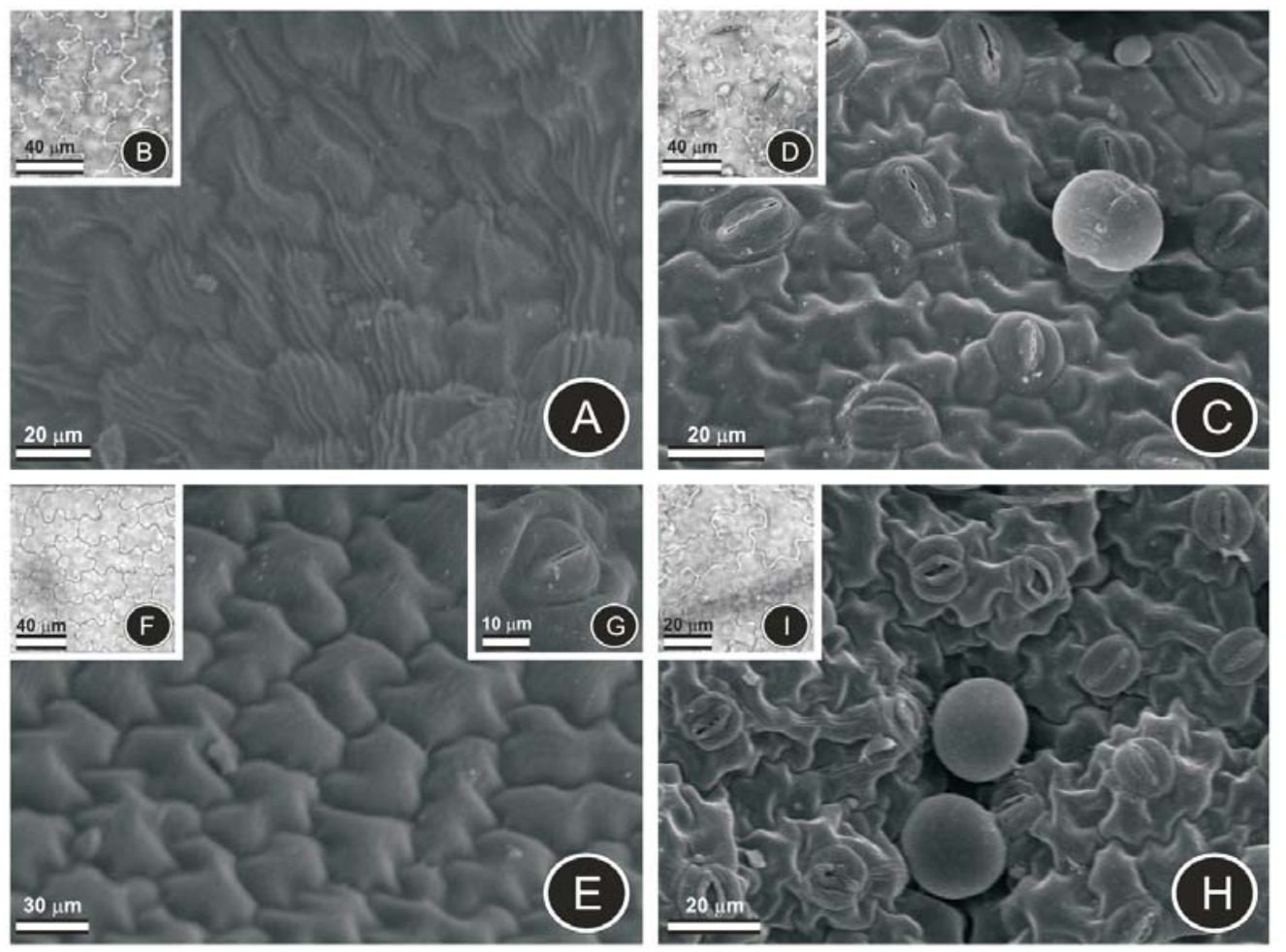

Figure 2 - Front view of the epidermis of the adaxial and abaxial surfaces of the Lantana camara and Lantana radula leaves showing anticlinal walls with winding outlines. A to D - L. camara. E to I - L. radula. C - Stomata at the same level of the epidermic cells. $\mathrm{H}$ - Irregular epidermis due to the presence of depressions. A, C, E, G and H-Scanning electron microscopy (SEM). B, D. F and $\mathrm{I}=$ Leaf clearing. A, B, E, F and G-Adaxial surfaces C, D, H and I-Abaxial surfaces.

\section{DISCUSSION}

Some of the anatomical characteristics of $L$. camara and $L$. radula were similar, such as simple leaf craspedodromus venation. The use of leaf venation for taxonomic studies (Moraes \& Paoli, 1999; Cardoso \& Sajo, 2006) should be considered with care (Dilcher, 1974). However, it was possible to identify diagnostic characteristics that allowed distinguishing one species of Lantana from the other.

In the petiole of the two Lantana species, the vascular system pattern organization and the secretory idioblasts (visualized only in the cortex of L. camara) are good distinctive characteristics. The anatomy of the petiole frequently supports the identification of some taxa, with the distal portion of the petiole being the most significant in terms of taxonomy (Howard, 1979). The petiole has been confirmed as a good taxonomic characteristic helping to distinguish species from the
Melastomataceae family (Reis et al., 2004) as well as in the separation of species of Erythroxylum P. Browne (Erythroxylaceae) (Bieras \& Sajo, 2004).

The thick cuticle on the adaxial surface of the two Lantana species can be interpreted as an adaptive strategy (Dickison, 2000; Larcher, 2000, Machado et al., 2008). The cuticle recovers the epidermis of the plant and acts as an interface between the inside and outside of the organism (Bukovac et al., 1990) and must be considered in the interventions aiming at the chemical control of plants (Procópio et al., 2003; Ferreira et al., 2007).

The sinuosity of the epidermis cells appears to be fixed genetically (Arruda, 1994) or could also be considered as a response to environmental conditions (Alquini et al., 2003), once they increase the contact surface between adjacent cells (Wylie, 1943) and rigidity (Haberlandt, 1928). In the present investigation the results showed that this was not a good distinctive characteristic. 

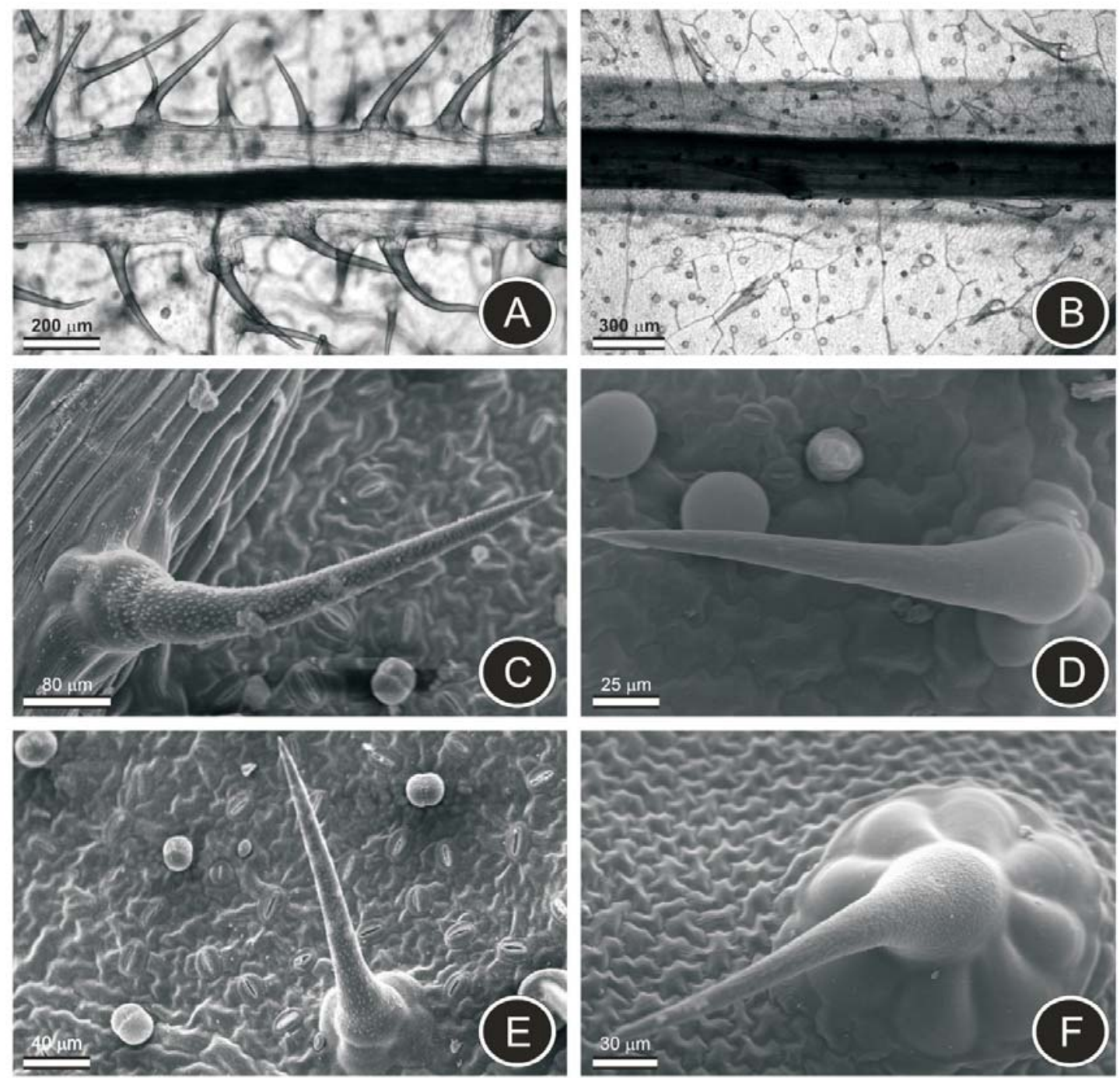

Figure 3 - Nonglandular trichomes of Lantana camara and Lantana radula. A, C and E - L. camara. B, D and F - L. radula $\mathrm{A}$ and $\mathrm{B}-$ Leaf clearing. C, D, E, F-Scanning electron microscopy (SEM).

Stomata distribution did not differ in the two species studied, being both amphistomatic, with a greater number of stomata in the abaxial surface. Stomata in two leaf surfaces characterize some species of the Verbenaceae family (Metcalfe \& Chalk, 1950; Inamdar, 1969) and are ecologically less variable characters (Dilcher, 1974). The anphistomatic leaves generally present larger quantities of stomata in the epidermis of the abaxial surface (Greulach, 1973), to which it seems to be a preventive mechanism against photoinhibition, since the adaxial surface is more exposed to solar radiation, as most of the leaves are in the horizontal position (Smith et al., 1998).
The glandular and nonglandular trichomes, observed for both Lantana species (Figure 5 and 6), are distributed widely in the Verbenaceae family (Solereder, 1908; Metcalfe \& Chalk, 1950) including some Lantana species (Solereder, 1908; Metcalfe \& Chalk, 1950; Inamdar, 1969; Moura et al., 2005). Trichomes, particularly the secretory ones, are considered important tools for taxonomy (Solereder, 1908; Metcalfe \& Chalk, 1950; Fahn, 1979; Theobald et al., 1979).

The unicellular nonglandular trichomes observed in the two species of Lantana have been described for plants of this genus (Solereder, 1908; Metcalfe \& Chalk, 1950) 

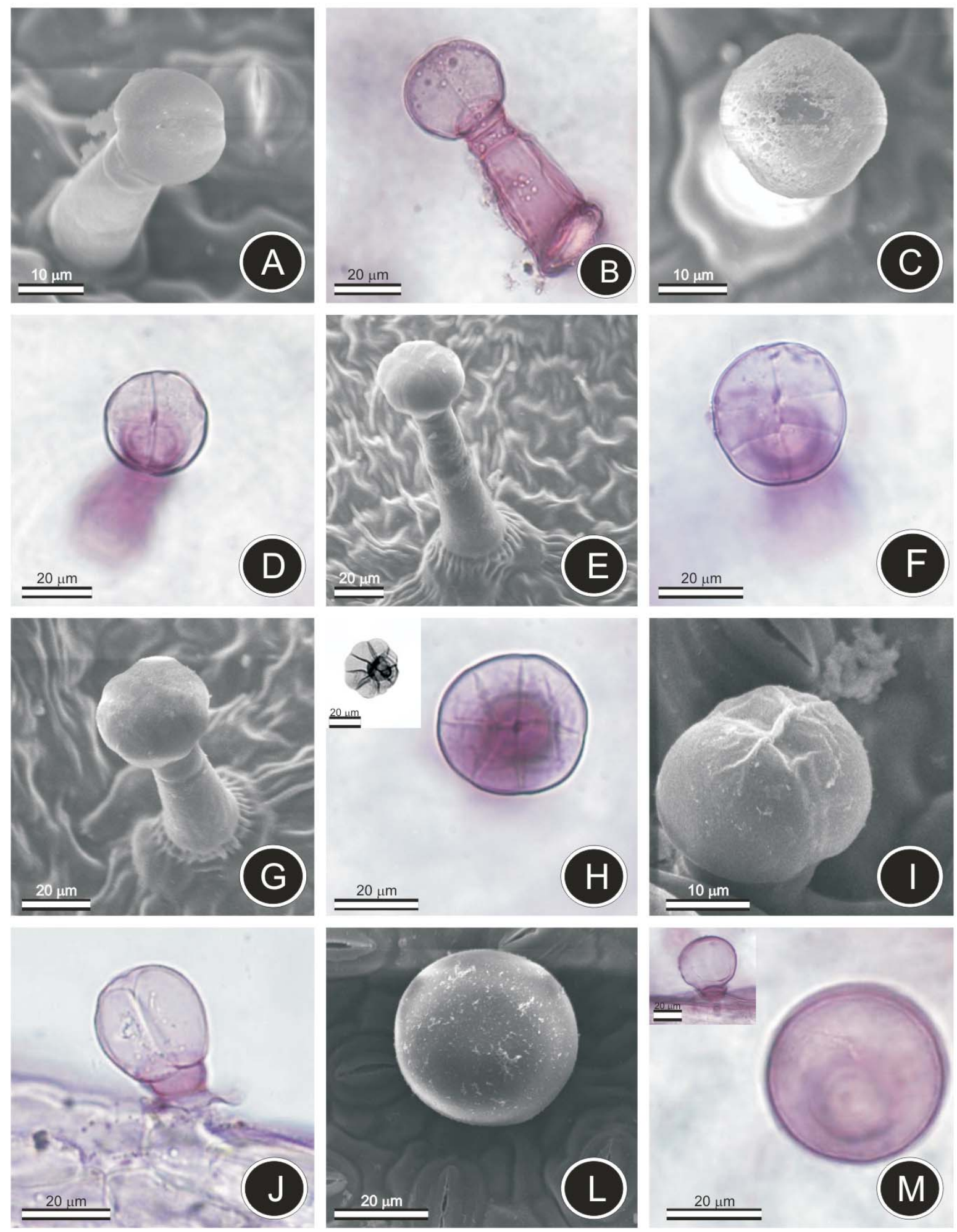

Figure 4 - Types of glandular trichomes in Lantana camara. A, C, E, G, I, L-Scanning electron microscopy (SEM) B, D, F, H, J, MLeaf clearing. A and B-Capitate trichomes of type I with two cells in the secretory head. C and D-Capitate trichomes of type I with four cells in the secretory head. E and F-Capitate trichomes of type I, with six cells in the secretory head.G and H-Capitate trichomes of type I with eight cells in the secretory head. Detail: Secretory head. I and J-Capitate trichomes of type II with two cells in the secretory head. L and M-Capitate trichomes of type III, unicellular. Detail: side view. 
including L. camara (Inamdar, 1969; Moura et al., 2005). The largest frequency of these trichomes in the adaxial surface of $L$. camara can be related to several factors such as protection against excessive radiation and high temperatures, as reported in the literature (Francino et al., 2006; Hallahan \& Gray, 2000; Valkama et al., 2003). However, in most cases, the true ecological function of the trichomes has not been supported by experimental data (Werker, 2000). The penetration of herbicides in the plant tissues is essential for the effective chemical control of weed (Procópio et al., 2003). The anatomical characteristics practically determine the ease with which these products can be absorbed (Hess \& Falk, 1990). Trichomes in the leaf surface can intercept pulverized drops, preventing these from reaching the epidermis. The efficiency of herbicide absorption by the trichomes and their translocation to the epidermic cells are still partially unknown (Hess \& Falk, 1990). However, the absorption of these substances can in part take place through the trichomes (Hull, 1970). Some authors consider that trichomes, especially the nonglandular types, are an efficient point for the penetration of herbicides in the plant tissue. Hess \& Falk (1990), observed the negative relation between herbicide adherence in trichomes and the efficiency of these products. Thus, the high frequency of non-glandular trichomes in the adaxial surface of $L$. camara would be advantageous for the
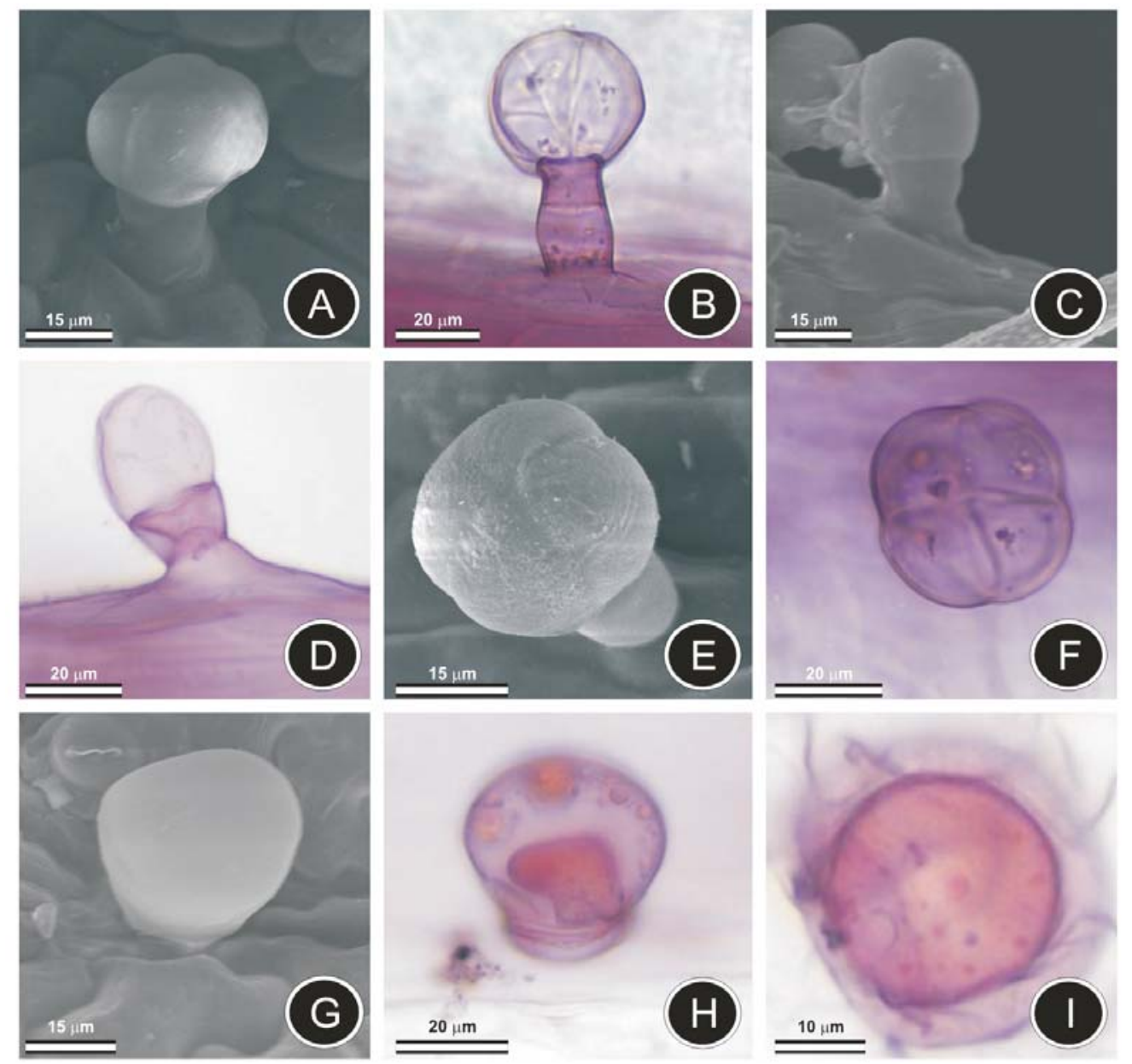

Figure 5 - Types of glandular trichomes in Lantana radula. A, C, E and G - Scanning electron microscopy (SEM). B, D, F, H and I - Leaf clearing. A and B - Capitate trichomes of type I with four cells in the secretory head. C, D, E and F-Capitate trichomes of type II with one or four cells in the secretory head. G, H, I - Capitate trichome of type III, unicellular. 
species when undergoing chemical control strategies. Unsuitable chemical control would be prone to negatively affect $L$. radula since this plant has a low frequency of non-glandular trichomes in the adaxial surface (Table 1), rendering the epidermic cells more exposed to the agrochemical action.

The different types of capitate glandular trichomes described for the two species are important distinctive characteristics. The Verbenaceae family stands out for presenting different types of glandular trichomes. Considering the large number of Lantana species, few studies describing such structures are available. Furthermore, the lack of standardization in the classification of these trichomes limits the use of this characteristic for taxonomic studies (Inamdar, 1969; Cantino, 1990; Moura et al., 2005). Lamiaceae, a family phylogenetically related to the Verbenaceae family, presents a different type of capitate trichomes, with the various classifications of the trichomes resulting in confusion and rendering difficult the comparison between the reported studies in the literature (Werker, 1993; Corsi \& Bottega, 1999; Ascensão et al., 1999).

Table 1 - Middle values of the frequency of the non-glandular and glandular trichomes for $\mathrm{mm}^{2}$ in the abaxial and adaxial surfaces of Lantana camara and Lantana radula leaves

\begin{tabular}{|c|c|c|c|c|}
\hline \multirow{2}{*}{ Surface } & \multicolumn{2}{|c|}{ Nonglandular trichomes } & \multicolumn{2}{c|}{ Glandular trichomes } \\
\cline { 2 - 5 } & L. camara & L. radula & L. camara & L radula \\
\hline $\mathrm{AB}$ & $2.8 \mathrm{~B}$ & $0.3 \mathrm{~A}$ & $21.2 \mathrm{~A}$ & $23.0 \mathrm{~A}$ \\
\hline $\mathrm{AD}$ & $5.2 \mathrm{~A}$ & $0.9 \mathrm{~A}$ & $1.7 \mathrm{~B}$ & $0.6 \mathrm{~B}$ \\
\hline
\end{tabular}

Means followed by the same letter do not differ at $5 \%$ probability by the Tukey test. $\mathrm{AD}=$ adaxial, $\mathrm{AB}=$ abaxial.
The glandular trichomes in the two species, are more abundant in the abaxial surface than in the adaxial. Aromatic plants grow in sunny environments and the trichomes, being protected in the abaxial surface, allow the secretions to remain for an extended time in the plant. L. camara is rich in essential oils (Misra \& Laatsch, 2000; Alitonou et al., 2004; Randrianalijaona et al., 2005) and these compounds normally evaporate and are released under high temperatures and low humidity. In L. radula, the trichomes (mainly those of type III) occur in depressions, which reinforce the hypothesis of protection. The glandular trichomes present ecological significance, being associated with the plant interaction with the environment, interfering efficiently against the attack of herbivores and pathogens (Werker, 1993). Based on the results obtained, it can be suggested that the occurrence of glandular trichomes can be considered an important distinctive characteristic for $L$. camara and $L$. radula.

L. radula presents an irregular abaxial surface resulting in depressions, while in L. camara a flat surface is observed. This characteristic represents an additional distinction between the two species. The dorsiventral arrangement observed in the two studied Lantana species is characteristic of the Verbenaceae family (Metcalfe \& Chalk, 1950).

Secretory idioblasts were observed only in L. camara and the crystalliferous idioblasts containing styloid crystals were found only in $L$. radula. These two characters are useful in distinguishing the species. Biosynthesis or storage of pentacyclic triterpenoids from this plant could occur in the idioblasts (Sharma et al., 1988; Moura et al., 2005). The

Table 2 - Middle values of the frequency of the nonglandular and glandular trichomes for $\mathrm{mm}^{2}$ in the base, median and apical regions of Lantana camara and Lantana radula leaves

\begin{tabular}{|c|c|c|c|c|c|c|c|c|}
\hline \multirow{2}{*}{ Region } & \multicolumn{4}{|c|}{ Non-glandular trichomes } & \multicolumn{4}{c|}{ Glandular trichomes } \\
\cline { 2 - 10 } & \multicolumn{2}{|c|}{ L. camara } & \multicolumn{2}{c|}{ L. radula } & \multicolumn{2}{c|}{ L. camara } & \multicolumn{2}{c|}{ L. radula } \\
\cline { 2 - 10 } & $\mathrm{AD}$ & $\mathrm{AB}$ & $\mathrm{AD}$ & $\mathrm{AB}$ & $\mathrm{AD}$ & $\mathrm{AB}$ & $\mathrm{AD}$ & $\mathrm{AB}$ \\
\hline $\mathrm{BA}$ & $5.3 \mathrm{~A}$ & $2.7 \mathrm{~A}$ & $0.9 \mathrm{~A}$ & $0.4 \mathrm{~A}$ & $2.1 \mathrm{~A}$ & $23.5 \mathrm{~A}$ & $0.6 \mathrm{~A}$ & $22.5 \mathrm{~B}$ \\
\hline $\mathrm{RM}$ & $4.2 \mathrm{~A}$ & $3.27 \mathrm{~A}$ & $0.8 \mathrm{~A}$ & $0.3 \mathrm{~A}$ & $1.7 \mathrm{~A}$ & $19.3 \mathrm{~A}$ & $0.5 \mathrm{~A}$ & $26.2 \mathrm{~A}$ \\
\hline $\mathrm{AP}$ & $6.1 \mathrm{~A}$ & $2.53 \mathrm{~A}$ & $1.0 \mathrm{~A}$ & $0.2 \mathrm{~A}$ & $1.4 \mathrm{~A}$ & $20.7 \mathrm{~A}$ & $0.6 \mathrm{~A}$ & $20.6 \mathrm{~B}$ \\
\hline
\end{tabular}

Means followed by the same letter do not differ at $5 \%$ probability by the Tukey test. $\mathrm{AD}=$ adaxial, $\mathrm{AB}=$ abaxial, $\mathrm{BA}=$ base, $\mathrm{RM}=$ median region and $\mathrm{AP}=$ apex. 

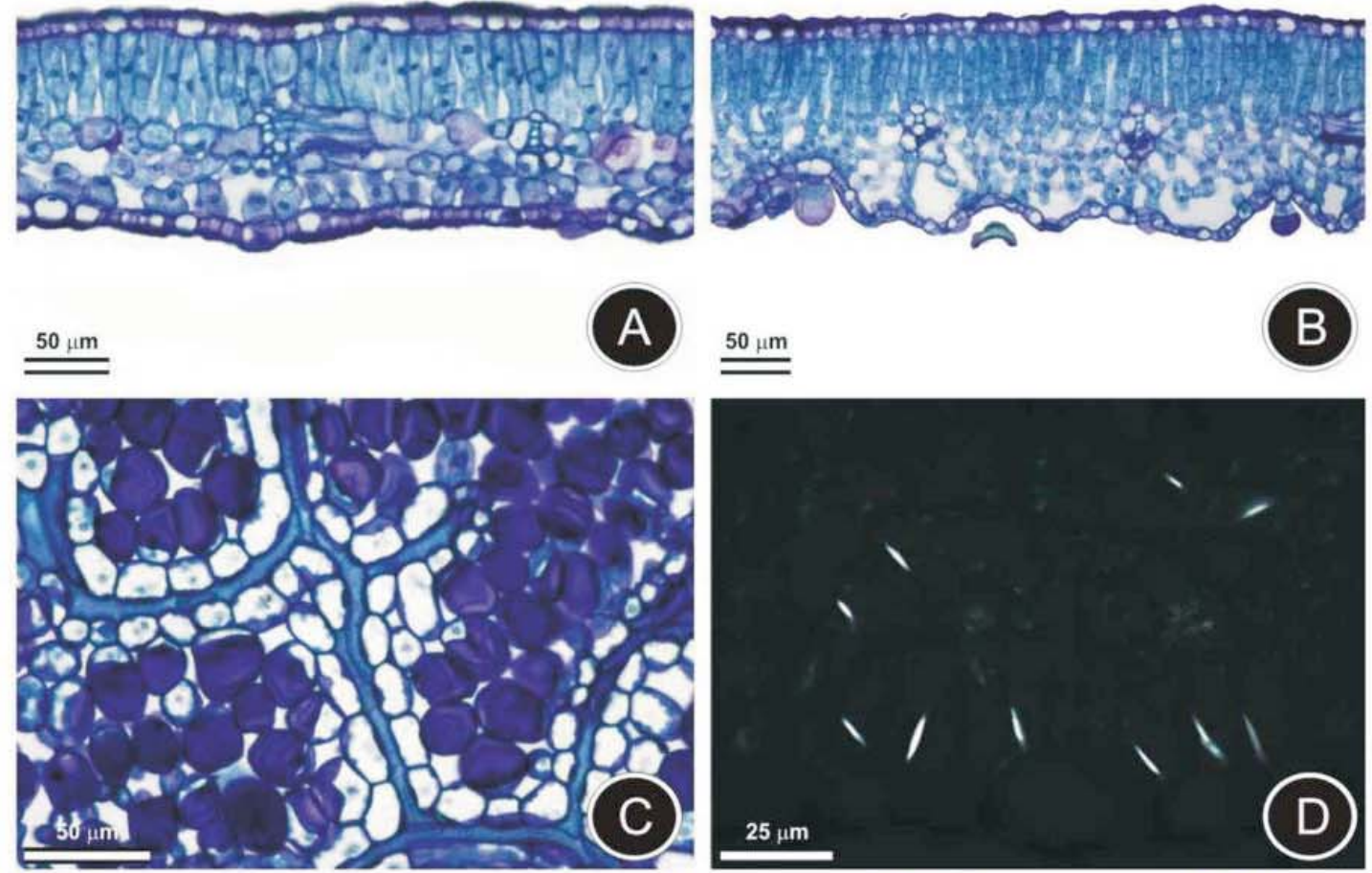

$50 \mu \mathrm{m}$
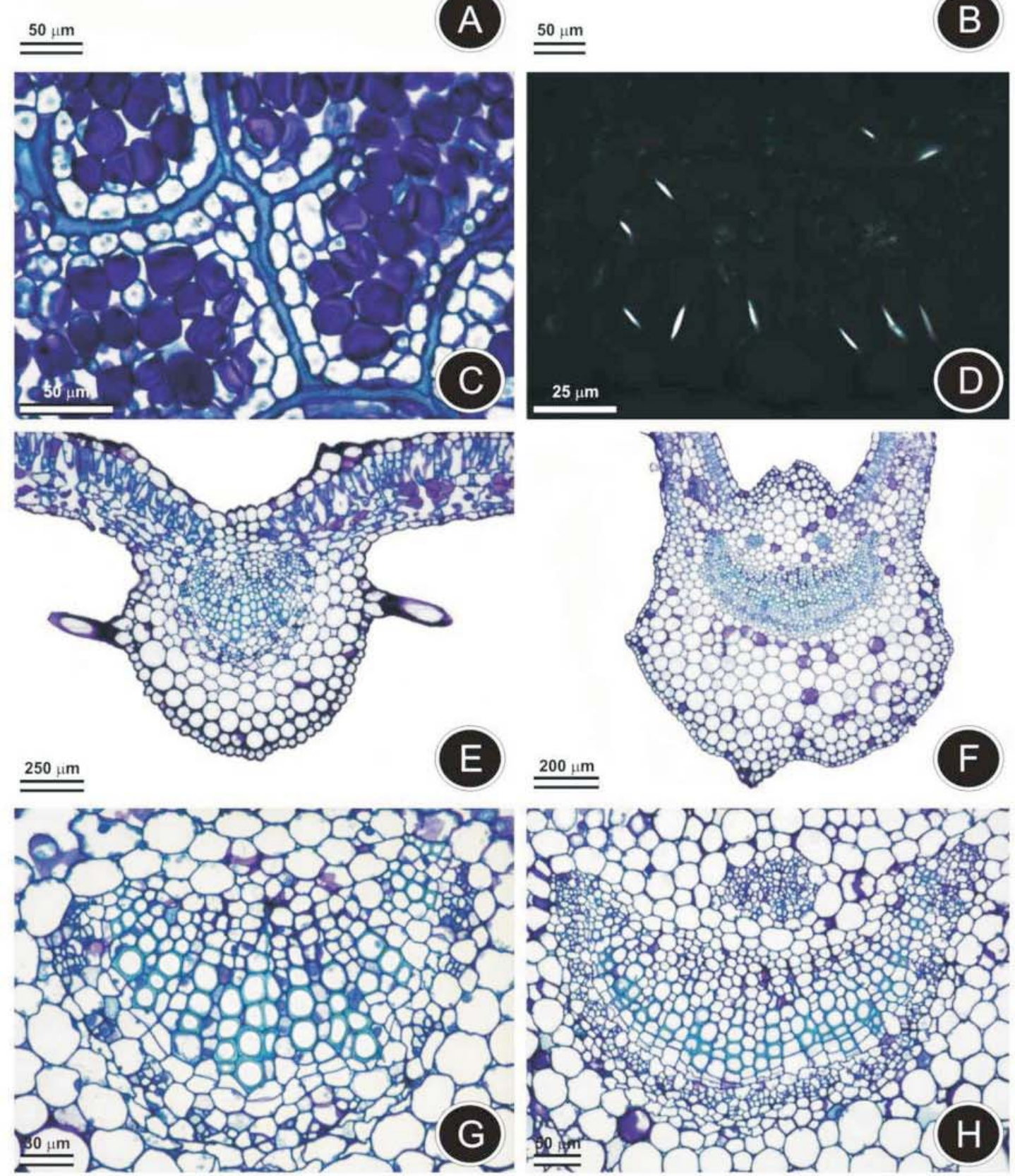

Figure 6 - Sections of Lantana camara and Lantana radula leaf blades stained with Blue Toluidine. A, C, E and G - L. camara. B, D, F and H-L. radula. A and B - Transversal section of the leaf blade showing mesophyll dorsiventral. C - Paradermal section of the leaf blade showing the secretory idioblasts. D - Detail of the cortex showing the crystalliferous idioblasts under polarized light. E to F - General aspect of the median vein of leaves. G and H - Detail of the vascular bundle showing xylem and phloem. 
morphology and distribution of these crystals is a constant characteristic among the species (Franceschi, 2005), being important for taxonomic purposes (Lersten \& Horner, 2000; Prychid, 2003), as its deposition is genetically controlled (Franceschi, 2005).

The results presented in this paper allowed the identification of leaf characteristics useful for the distinction of two morphologically similar species of Lantana. The anatomical description of $L$. radula is presented for the first time, which contributes to further knowledge of the Verbenaceae family.

\section{ACKNOWLEDGEMENTS}

We would like to thank the Brazilian agencies Conselho Nacional de Desenvolvimento Científico e Tecnológico (CNPq) for granting the research fellowships (LCAB); Coordenação de Aperfeiçoamento de Pessoal de Nivel Superior (CAPES) for granting a scholarship (JLP); and Fundação de Amparo a Pesquisa do Estado de Minas Gerais (FAPEMIG), for its financial support. We would also like to thank the Núcleo de Microscopia e Microanálise da Universidade Federal de Viçosa (NMM) for the SEM work; Prof. Luzimar Campos da Silva, for her comments and assistance with the electronic microscopy work and Prof. Tania Regina dos Santos Silva for plant identification.

\section{LITERATURE CITED}

ALQUINI, Y. et al. Epiderme. In: GLÓRIA, B. A.; GUERREIRO, S. M. C. Anatomia vegetal. 2.ed. Viçosa, MG: Universidade Federal de Viçosa, 2006. p. 87-96.

ALITONOU, G. et al. Composition chimique et activités biologiques de l'huile essentielle de Lantana camara Linn. Comp. Rendus Chime, v. 7, n. 10-11, p. 1101-1105, 2004.

ALVES, M. V. et al. Aplicações taxonômicas da anatomia foliar de espécies brasileiras de Hypolytrum Rich (Cyperaceae). R. Bras. Bot., v. 25, n. 1, p. 1-9, 2002.

ASCENSÃO, L.; MOTA, L.; CASTRO, M. M. Glandular trichomes on the leaves and flowers of Plectranthus ornatus: morphology, distribution and histochemistry. Ann. Bot., v. 84, n. 4 , p. $437-447,1999$.

ARRUDA, R. C. O. Anatomia foliar de Trilepis lhotzkiana Ness. e Trilepis ciliatifolia T. Koyama Cyperaceae. 1994. 119 f. Dissertação (Mestrado em Botânica) - Universidade Federal do Rio de Janeiro, Rio de Janeiro, 1994.
BARRETO, R. W.; EVANS, H. C.; ELLISON, C. A. The mycobiota of the weed Lantana camara in Brazil, with particular reference to biological control. Mycol. Res., v. 99, n. 7, p. 769-782, 1995.

BIERAS, A. C.; SAJO, M. G. Anatomia foliar de Erythroxylum P. Browne (Erythroxylaceae) do Cerrado do estado de São Paulo, Brasil. Acta Bot. Bras., v. 18, n. 3, p. 601-612, 2004.

BUKOVAC, M. J. et al. Sorption of organic compounds by plant cuticles. Weed Sci., v. 38, n. 3, p. 289-298, 1990.

CANTINO, P. D. The phylogenetic significance of stomata and trichomes in Labiatae and Verbenaceae. J. Arnold Arboretum, v. 71, n. 4, p. 323-370, 1990.

CARDOSO, C. M. V.; SAJO, M. G. Nervação foliar em espécies brasileiras de Myrtaceae Adans. Acta Bot. Bras., v. 20 , n. 3. p. $657-669,2006$

CORSI, G; BOTTEGA, S. Glandular hairs of Salvia officinalis: new data on morphology, localization and histochemistry in relation to function. Ann. Bot., v. 84, n. 5, p. 657-664, 1999.

DAY, M. D. et al. Lantana current management status and future prospects. Canberra: Australian Centre for International Agricultural Research, 2003. 134 p.

DILCHER, D. L. Approaches to the identification of angiosperms leaf remains. Bot. Rev., v. 40, n. 1, p. 1-157, 1974.

DICKISON, W. C. Integrative plant anatomy. New York: Academic Press, 2000. 534 p.

FAHN, A. Secretory tissues in plants. London: Academic Press, 1979. $302 \mathrm{p}$.

FERREIRA, E. A. et al. Leaf blade quantitative anatomy of sugarcane cultivars and clones. Planta Daninha, v. 25, n. 1, p. 25-34, 2007.

FRANCESCHI, V. R.; NAKATA, P. A. Calcium oxalate in plants: formation and function. Ann. Rev. Plant. Biol., v. 56, n. 1, p. 41-71, 2005.

FRANCINO, D. M. T et al. Anatomia foliar e caulinar de Chamaecrista trichopoda (Caesalpinioideae) e histoquímica do nectário extrafloral. Planta Daninha, v. 24, n. 4, p. 695-705, 2006.

GREULACH, V. A. Plant function and structure. New York: Collier Macmillan, 1973. 575 p.

HABERLANDT, G. Physiological plant anatomy. London: Macmillan \& Co, 1928. $511 \mathrm{p}$

HESS, F. D.; FALK, R. H. Herbicide deposition on leaf surfaces. Weed Sci., v. 38, n. 3, p. 280-288, 1990.

Planta Daninha, Viçosa-MG, v. 27, n. 4, p. 689-700, 2009 
HOWARD, R. A. The petiole. In: METCALFE, C. R.; CHALK, L. Anatomy of the Dycotyledons. Oxford: Oxford Claredon Press, 1979. v. 1. p. $88-96$

HULL, H. M. Leaf structure as related to absorption of pesticides and other compounds. Res. Rev., v. 31, n. 1, p. $1-155,1970$

INAMDAR, J. A. Epidermal structure and ontogeny of stomata in some Verbenaceae. Ann. Bot., v. 33, n. 1, p. 55-66, 1969.

JOHANSEN, D. A. Plant microtechnique. New York: Mc Graw-Hill Book Co, 1940. 523 p.

KRAUS, J. E.; ARDUIM, M. Manual básico de métodos em morfologia vegetal. Rio de Janeiro: EDUR, 1997. 198 p.

LARCHER, W. Ecofisiologia vegetal. São Carlos: Rima Artes e Textos, 2000. $531 \mathrm{p}$.

LERSTEN, N. R.; HORNER, H. T. Calcium oxalate crystal types and trends in their distribution patterns in leaves of Prunus (Rosaceae : Prunoideae). Plant Syst. Evol., v. 224, n. 1, p. $83-96,2000$

MACHADO, A. F. L et al. Caracterização anatômica de folha, colmo e rizoma de Digitaria insularis.

Planta Daninha, v. 26, n. 1, p. 1-8, 2008

METCALFE, C. R.; CHALK, L. Anatomy of the dicotyledons: leaves, stem and wood in relation to taxonomy with notes on economic uses. Oxford: Oxford Clarendon Press, 1950. v. $1.1500 \mathrm{p}$

MISRA, L.; LAATSCH, H. Triterpenoids, essential oil and photo-oxidative 28-13-lactonization of oleanolic acid from Lantana camara. Phytochemistry, v. 54, n. 8, p. 969-974, 2000.

MORAES, P. L. R.; PAOLI, A. A. S. Epiderme e padrão de venação foliar de espécies de Lauraceae. Acta Bot. Bras., v. 13, n. 1, p. $87-97,1999$.

MOURA, M. Z. D.; ISAIAS, R. M. S.; SOARES, G. L. G. Ontogenesis of internal secretory cells in leaves of Lantana camara (Verbenaceae). Bot. J. Linn. Soc., v. 148, n. 1, p. $427-431,2005$.

O'BRIEN, T. P.; McCULLY, M. E. The study of plant structure principles and selected methods. Melbourne: Termarcarphi Pty, 1981. 316 p.

PRYCHID, C. J.; FURNESS, C. A.; RUDALL, P. J Systematic significance of cell inclusions in Haemodoraceae and allied families: silica bodies and tapetal raphides. Ann.

Bot., v. 92, n. 4, p. 571-580, 2003

PROCÓPIO, S. O. et al. Leaf Anatomical Studies in Weed Species Widely Common in Brazil. III - Galinsoga parviflora, Crotalaria incana, Conyza bonariensis and Ipomoea cairica. Planta Daninha, v. 21, n. 1, p. 1-9, 2003
RANDRIANALIJAONA, J. et al. Seasonal and chemotype influences on the chemical composition of Lantana camara $\mathrm{L}$ Essential oils from Madagascar. Anal. Chim. Acta, v. 545, n. 1, p. $46-52,2005$

REIS, C.; PROENÇA, S. L.; SAJO, M. G. Vascularização foliar e anatomia do pecíolo de Melastomataceae do cerrado de São Paulo, Brasil. Acta Bot. Bras., v. 18, n. 4, p. 987-999, 2004.

SALIMENA, F. R. G. New synonyms and typifications in Lippia sect. Rhodolippia (Verbenaceae). Darwiniana, v. 40, n. 1/2, p. 121-125, 2002.

SARTORI, A. L. B.; TOZZI, A. M. G. A. Comparative leaflet anatomy in Microcarpus Allemão, Myroxylon L. f. and Myrospermum Jacq. (Leguminosae-Papilionidae-Sophoreae) species. Bot. J. Linn. Soc., v. 13, n. 1, p. 29-41, 2002.

SHARMA, O. P.; MAKKAR, H. P. S.; DAWRA, R. K. A review of the noxious plant Lantana camara. Toxicon, v. 26, n. 11, p. $975-987,1988$

SILVA, T. R. S. Redelimitação e revisão taxonômica do gênero Lantana L. Verbenaceae no Brasil. 1999. $108 \mathrm{f}$. Tese (Doutorado em Botânica) - Universidade Federal de São Paulo, São Paulo, 1999.

SMITH, W. K.; BELL, D. T; SHEPHERD, K. A. Associations between leaf structure, orientation and sunlight exposure in five western Australian communities. Am. J. B., v. 85, n. 1, p. $56-63,1998$.

SOLEREDER, H. Systematic anatomy of the dicotyledons. Oxford: Clarendon Press, 1908. 643 p

THEOBALD, W. L.; KRAHULIK, J. L.; ROLLINS, R. Trichome description and classification. In: METCALFE C R.; CHALK, L. (Eds.). Anatomy of the dicotyledons, systematic anatomy of the leaf and stem. Oxford: Oxford Clarendon Press, 1979. v. 1. p. 40-53

VALKAMA, E. et al. Comparative analysis of leaf trichome structure and composition of epicuticular flavonoids in Finnish Birch species. Ann. Bot., v. 91, n. 6, p. 643-655, 2003.

WERKER, E. Function of essential oil-secreting glandular hairs in aromatic plants of the Lamiaceae. A review. Flav. Fragr. J., v. 8, n. 1, p. 249-255, 1993

WERKER, E. Trichome diversity and development. In: HALLAHAN, D. L.; GRAY, J. C.; CALLOW, J. A. (Eds.) Advances in botanical research, incorporating advances in plant pathology - Plant trichomes. San Diego: Academic Press, 2000. v. 31. p. 1-35.

WYLIE, R. B. The role of epidermis in the foliar organization and its relations to the minor venation. Am. J. Bot., v. 30, n. 1, p. 273-280, 1943. 